\title{
Impact of Germination on Biochemical and Antioxidant Enzymes of Ceiba pentandra (Kapok) Seeds
}

\author{
Chekuboyina Ravi Kiran ${ }^{1 *}$, Dadi Bhaskar Rao ${ }^{1}$, Nagala Sirisha ${ }^{1}$, Tamanam Raghava Rao ${ }^{1}$ \\ ${ }^{1}$ Department of Biochemistry, College of Science and Technology, Andhra University, Visakhapatnam, India. \\ Email: *ravi79biochem@gmail.com
}

Received March 29 ${ }^{\text {th }}, 2012$; revised April 27 $7^{\text {th }}, 2012$; accepted May $6^{\text {th }}, 2012$

\begin{abstract}
Changes in biochemical components and the activities of superoxide dismutase (SOD), catalase (CAT), peroxidase (POD), glutathione peroxidase (GPx) and ascorbate oxidase (AO) in germinating and non-germinating seeds of Ceiba pentandra were evaluated in the present study. Results show that the levels of proteins and total soluble sugars are high and reducing sugars and free amino acids are low in non-germinating seeds whereas the contrary was observed in 4 days old germinating seeds. Enzymatic antioxidants like SOD, CAT, POD, GPx and AO showed enhanced activities during seed germination. Our findings indicate that three days after germination of Ceiba pentandra seeds, their palatability significantly improve. The nutritive utilization of protein and carbohydrates along with efficient participation of antioxidant mechanisms, including the synergistic activities of the different types of SOD, CAT, POD, GPx and AO, might play an important role during seed germination. The conclusion of this inquiry is that the germinating seeds can serve as natural antioxidant agents, setting ahead the possibility of employing them for therapeutic purposes.
\end{abstract}

Keywords: Amino Acids; Ascorbate Oxidase; Catalase; Germination; Glutathione Peroxidase; Peroxidase; Reducing Sugars; Superoxide Dismutase

\section{Introduction}

Seed germination and post-germination seedling development are well-regulated processes in plant physiology involving high metabolic activity and generation of reactive oxygen species (ROS) in the cell [1]. ROS affect various aspects of seed physiology, displaying two major functions: as a kind of cytotoxin and as a special role in seed development, dormancy breakage, and in defence against biotic and abiotic stresses [2]. A series of new roles for ROS has recently been identified: the control and regulation of biological processes, such as cell cycle, programmed cell death and hormone signaling [3]. These studies extend our understanding of ROSs and suggest a dual role for ROS in plant biology as both toxic byproducts of aerobic metabolism and key regulators of growth, development and defence pathways. ROS are produced in aerobic organisms within the cell and are normally in balance with antioxidant molecules. Oxidative stress arises from an imbalance between generation and elimination of ROS. These cytotoxic activated ROS can seriously disrupt normal metabolism through oxidative damage to lipids, protein and nucleic acids, selective permeability of bio-membranes, causing membrane leakage and changes in the activity of membrane-bound en-

"Corresponding author. zymes [2]. However, an elaborate and highly redundant plant ROS defence network, composed of antioxidant enzymes, antioxidants and ROS-producing enzymes, is responsible for maintaining ROS levels under tight control. In plant cells, antioxidant enzymes, such as superoxide dismutase (SOD), glutathione peroxidase (GPx), peroxidase (POD), catalase (CAT) and ascorbate oxidase (AO), are considered to form a defensive team, whose combined purpose is to protect cells from oxidative damage during growth, development and senescence [4].

Thus the key objective of this study was to determine the impact of germination on biochemical and enzymatic antioxidant activities of Ceiba pentandra seeds belonging to the order Malvalea and the family Malvaceae.

\section{Materials and Methods}

\subsection{Chemicals}

Chemicals and reagents used for antioxidant estimations were purchased from Merck. All additional chemicals used were analytical grade. Altogether the experiments were performed at room temperature unless otherwise stated.

\subsection{Collection of Seeds}

Mature Dried fruits of Ceiba pentandra were obtained 
from in and around Andhra University area, Visakhapatnam, India. Healthy seeds were selected and washed thoroughly with running tap water and with $5 \%(\mathrm{w} / \mathrm{v})$ Teepol for 10 minutes followed by treatment with bavistin, a commercial fungicide for 5 minutes. Then the seeds were subsequently surface sterilized with $0.1 \%$ (w/v) $\mathrm{HgCl}_{2}$ for 5 minutes and then washed with sterile distilled water. The seeds were soaked for 24 hours before they were kept for germination [5] in sterile Petri-plates with double layered moistened filter paper. The germination was carried out at $30^{\circ} \mathrm{C}$ with 16 hours light and 8 hours dark [6]. Radicle emergence of $1 \mathrm{~cm}$ was used as a reference to consider seed germination. The 4 days germinated seeds were used for biochemical and antioxidant analysis.

\subsection{Determination of Proteins, Amino Acids, Total Soluble Sugars and Reducing Sugars}

One gram of non-germinating (soaked overnight in $0.2 \mathrm{M}$ Tris $\mathrm{HCl}$ Buffer, $\mathrm{pH} 7.2$ ) and germinating Ceiba pentandra seeds were homogenized separately with $20 \mathrm{ml}$ of pre-chilled 0.2 M Tris HCl Buffer, $\mathrm{pH}$ 7.2, containing 0.1 mM EDTA in chilled pestle and mortar. The homogenates were squeezed through double layered cheese cloth and centrifuged (Sorvall Instrument RC5C, Rotor SS-34) at $16,000 \mathrm{rpm}$ for 15 minute at $4^{\circ} \mathrm{C}$. One $\mathrm{ml}$ of above extract was taken and $1 \mathrm{ml}$ of ice cold $20 \%$ TCA was added [7]. The pellet was washed twice with acetone and again centrifuged at $8000 \mathrm{rpm}$. Supernatant was discarded and pellet was dissolved in $5 \mathrm{~mL}$ of $0.1 \mathrm{~N} \mathrm{NaOH}$. This was used for protein estimation. Total proteins were estimated by the method of Lowry et al. [8] using BSA as standard. Soluble sugars and free amino acids were determined by phenol sulphuric acid method using glucose as standard [9] and ninhydrin method using leucine as standard [10].

\subsection{Assay of Superoxide Dismutase}

The assay of superoxide dismutase was carried out based on the reduction of Nitroblue tetrazolium (NBT) [11]. To $0.5 \mathrm{ml}$ of seed extract, $1 \mathrm{ml} 125 \mathrm{mM}$ of Sodium Carbonate, $0.4 \mathrm{ml}$ of $24 \mu \mathrm{M} \mathrm{NBT}$ and $0.2 \mathrm{ml}$ of $0.1 \mathrm{mM}$ EDTA were added. The reaction was initiated by adding $0.4 \mathrm{ml}$ of $1 \mathrm{mM}$ Hydroxylamine hydrochloride. Zero time absorbance was taken at $560 \mathrm{~nm}$ using spectrophotometer, followed by recording the absorbance after $5 \mathrm{~min}$ at $25^{\circ} \mathrm{C}$. The control was simultaneously run without seed extract. Units of SOD were expressed as amount of enzyme required for inhibiting the reduction of NBT by $50 \%$. The specific activity was expressed in terms of Units per $\mathrm{mg}$ of protein.

\subsection{Assay of Catalase}

Catalase activity was determined by the titrimetric method [12]. To $1 \mathrm{ml}$ plant extract, $5 \mathrm{ml}$ of $300 \mu \mathrm{M}$ phosphate buffer (pH 6.8) containing $100 \mu \mathrm{M}$ hydrogen peroxide $\left(\mathrm{H}_{2} \mathrm{O}_{2}\right)$ was added and left at $25^{\circ} \mathrm{C}$ for $1 \mathrm{~min}$. The reaction was arrested by adding $10 \mathrm{ml}$ of $2 \%$ sulphuric acid, and residual $\mathrm{H}_{2} \mathrm{O}_{2}$ was titrated with potassium permanganate $(0.01 \mathrm{~N})$ till pink colour was obtained. Units of enzyme activity were expressed as $\mathrm{ml}$ of $0.1 \mathrm{~N}$ potassium permanganate equivalents of $\mathrm{H}_{2} \mathrm{O}_{2}$ decomposed per $\mathrm{mg}$ protein per min.

\subsection{Assay of Peroxidase}

Assay of Peroxidase activity is carried out according to the procedure of Malik and Singh [13]. $3.5 \mathrm{ml}$ of phosphate buffer $(\mathrm{pH}$ 6.5) was taken in a clean dry cuvette, $0.2 \mathrm{ml}$ seed extract and $0.1 \mathrm{ml}$ of freshly prepared o-dianisidine solution was added. The temperature of assay mixture was brought to $28^{\circ} \mathrm{C}-30^{\circ} \mathrm{C}$ and then placed the cuvett in the spectrophotometer set at $430 \mathrm{~nm}$. Then, 0.2 $\mathrm{ml}$ of $0.2 \mathrm{M} \mathrm{H}_{2} \mathrm{O}_{2}$ was added and mixed. The initial absorbance was read and then, at every $30 \mathrm{sec}$ intervals up to $3 \mathrm{~min}$. A graph was plotted with the increase in absorbance against time. From the linear phase, the change in absorbance per min was read. Water blank was used in the assay. The enzyme activity was expressed in units per $\mathrm{mg}$ of protein per min.

\subsection{Assay of Glutathione Peroxidase}

Glutathione Peroxidase was assayed by the method of Rotruck et al. [14]. $0.2 \mathrm{ml}$ each of $0.8 \mathrm{mM}$ EDTA, 10 $\mathrm{mM}$ sodium azide, $1 \mathrm{mM} \mathrm{GSH}, 2.5 \mathrm{mM} \mathrm{H}_{2} \mathrm{O}_{2}, 0.32 \mathrm{M}$ phosphate buffer ( $\mathrm{pH} 7.0)$ and seed extract were mixed and incubated at $37^{\circ} \mathrm{C}$ for $10 \mathrm{~min}$. The reaction was arrested by the addition of $0.5 \mathrm{ml}$ of $10 \%$ TCA and the tubes were centrifuged. To $0.5 \mathrm{ml}$ of supernatant, $3.0 \mathrm{ml}$ of $0.33 \mathrm{mM}$ phosphate solution and $1.0 \mathrm{ml} 0.6 \mathrm{mM}$ DTNB reagent were added and the colour developed was read at $420 \mathrm{~nm}$ immediately. Graded amount of standards were also treated similarly. Glutathione peroxidase activity was expressed as $\mu \mathrm{g}$ of glutathione utilized per $\mathrm{mg}$ of protein.

\subsection{Assay of Ascorbate Oxidase}

To $3.0 \mathrm{ml}$ of ascorbate solution $(0.003 \%), 0.1 \mathrm{ml}$ of plant extracts were added and change in absorbance at $265 \mathrm{~nm}$ was measured at an interval of $30 \mathrm{~s}$ for a period of $5 \mathrm{~min}$. One unit of enzyme activity was expressed as $0.01 \mathrm{OD}$ change per mg of protein [15].

\section{Statistical Analysis}

The results of in vitro study were given as Mean \pm Stan- 
dard Deviation (SD) obtained from three independent experiments, and analyzed with Student's t-test for paired data and a "p" value less than 0.05 was considered as significant difference in the analysis.

\section{Results and Discussion}

\subsection{Biochemical Components}

The total protein content decreased during seed germination in ceiba pentandra seeds. The total protein content in non-germinating seeds was $27 \mathrm{mg} /$ gram tissue and decreased to $11.6 \mathrm{mg} / \mathrm{g}$ tissue in four days germinating seeds. On the contrary it was observed that there was an increase in the free amino acids from $2.20 \mathrm{mg} / \mathrm{g}$ of tissue in germinating seedlings to $0.78 \mathrm{mg} / \mathrm{g}$ of tissue in nongerminating seeds. It may be due to rapid hydrolysis of proteins, which would result in the release of free amino acids. Similar fallouts were reported by Ali Al-Heal [16] in Cassia senna seedlings. Considerable decrease in the protein content was observed in germinating Lupinus luteus and L. angustifolius [17] soybeans [18], Bambara groundnuts (Voandzeia subterranea L. Thouans) [19], fluted pumpkin (Telfairia occidentalis Hook) [20], and sunflower seeds (Helianthus annuus) [21]. The total soluble sugars content varied from $4 \mathrm{mg} / \mathrm{g}$ of tissue to 1.4 $\mathrm{mg} / \mathrm{g}$ of tissue and reducing sugars varied from 0.56 $\mathrm{mg} / \mathrm{g}$ of tissue and $1.26 \mathrm{mg} / \mathrm{g}$ of tissue in non-germinating and germinating seeds respectively. During germination, there was a decrease in storage carbohydrates and an increase of reducing sugars. This might be due to requirement of energy by growing plant at initial stages of seed germination. The outcomes acquired were presented in Figure 1(a). These results agree well with the results of Jaya and Venkataraman [22] in chickpea and green gram and also in white beans by Kon et al. [23].

\subsection{Antioxidant Activity}

The germination process modified the antioxidant activity; after a germination period of four days, Ceiba pentandra seeds showed higher antioxidant activity than raw seeds. Capacity measured by the constraints of enzymatic antioxidants includes SOD, CAT, POD, GPx and AO, all the activities increased with increasing concentrations ranging from 25 to $100 \mathrm{mg} / \mathrm{ml}$. In germinating seed extract higher enzymatic antioxidants at $100 \mathrm{mg} / \mathrm{ml}$ like SOD by $6.3 \pm 0.089$, CAT with $21.1 \pm 0.089$, peroxidase $69.2 \pm 0.15$, ascorbate oxidase through $0.84 \pm 0.0009$ and glutathione peroxidase with $836 \pm 0.89$ were detected against non-germinating seed extracts specifically SOD with $1.99 \pm 0.005$, CAT with $6.77 \pm 0.05$, peroxidase with $0.127 \pm 0.0009$, ascorbate oxidase with $0.29 \pm$ 0.0005 and glutathione peroxidase with $84 \pm 0.36$.

The control of steady-state ROS levels by SOD is an important protective mechanism against cellular oxida- tive damage, since $\mathrm{O}_{2}^{-}$acts as a precursor of more cytotoxic or highly relative ROS [24]. SOD has been established to work in collaboration with POD and CAT which act in tandem to remove $\mathrm{O}_{2}^{-}$and $\mathrm{H}_{2} \mathrm{O}_{2}$, respectively [4]. Early reports illustrate that increased SOD activities and cellular ROS levels were involved in the life of many plants including developmental course such as seed germination [25]. Enhanced SOD activity can be triggered by increased production of ROS or it might be a protective measure adopted by $C$. pentandra seeds against oxidative damage. Moreover, the changes of SOD activity in the degrading endosperms and developing cotyledons were correlated to those of POD and CAT activities. Our findings, shown in Figure 1(b) were also in line with previous reports symptomatic of the participation of SOD in the defense mechanism during germination and early seedlings development [26].

In oily seeds, CAT is particularly important in the early events of seedling growth, because it removes $\mathrm{H}_{2} \mathrm{O}_{2}$ produced during $\beta$-oxidation of the fatty acids [1]. In the present study, CAT activity was also examined, and a trend parallel to above was recorded; results are illustrated in Figure 1(c). Increased CAT activity could be an indication of the cellular evaluated ROS, since the amount of CAT present in aerobic cells is directly proportional to the oxidative state of the cells [2].

In plants, GPx and POD were considered to be associated with a number of essential metabolic processes, such as cell elongation, lignification, phenolic oxidation, pathogen defense and defense against stress [27,28]. Moreover, PODs probably play an important role in seed germination, growth, morphogenesis, and even in the final stage of senescence and death [29,30]. Changes in PODs activities occur during developmental process in tissue specific manner and differential regulation in response to germination process and plant species has been reported $[31,32]$. The present results indicate that PODs activities in the degrading endosperms and developing cotyledons were considerably greater than those of the raw seeds. Outcomes were laid on sight in Figures 1(d) and (e). Thus, increased PODs activities might be involved in the defence system during seed germination and early seedlings development.

AO catalyses the oxidation of L-AA (L-Ascobic acid) to MDHA (Monodehydroascorbate reductase) with the related reduction of molecular oxygen to water [33]. Increasing evidence links this enzyme to the modulation of cell expansion and/or cell division, possibly via control of the oxidation status of the L-AA/DHA redox pair [34, 35]. It is highly expressed in fast-growing tissues [36] and germinating pea seeds similar to that of above antioxidant enzymes. AO is also found localised mainly in the cell wall and AO mRNA and proteins are highly expressed in flowers, ovaries and very young fruits as well 


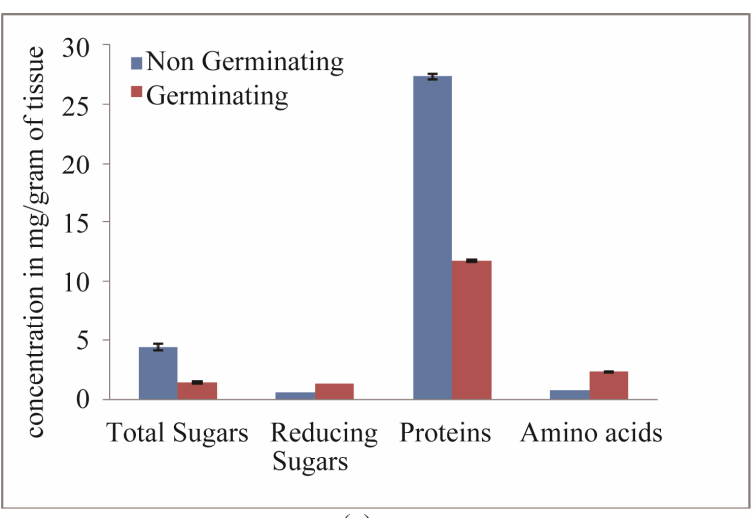

(a)

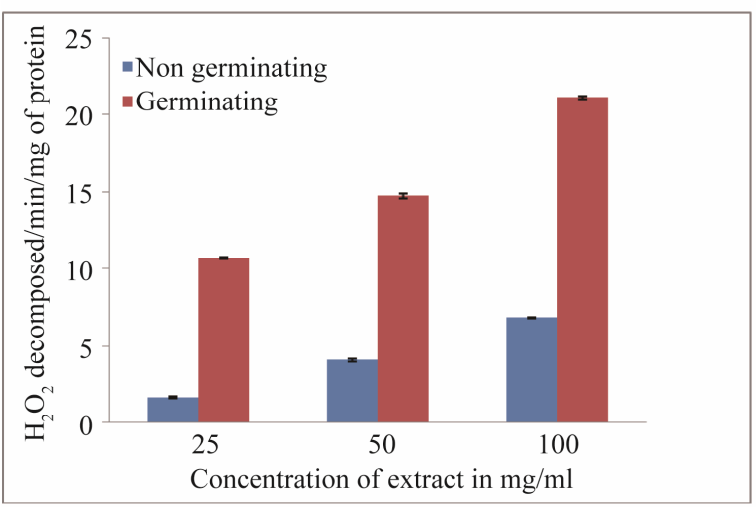

(c)

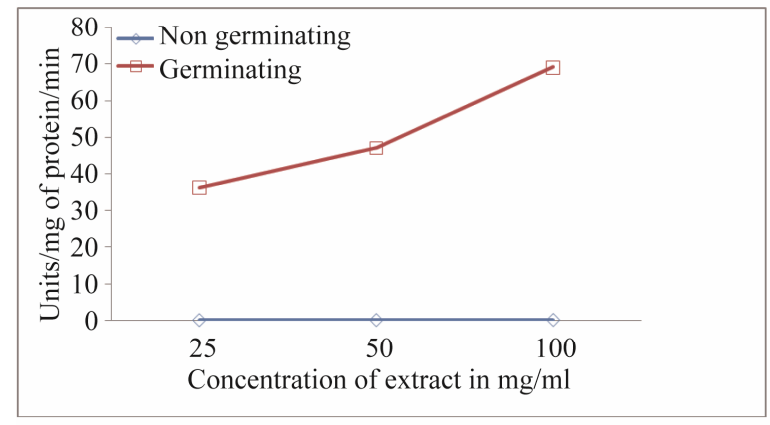

(e)

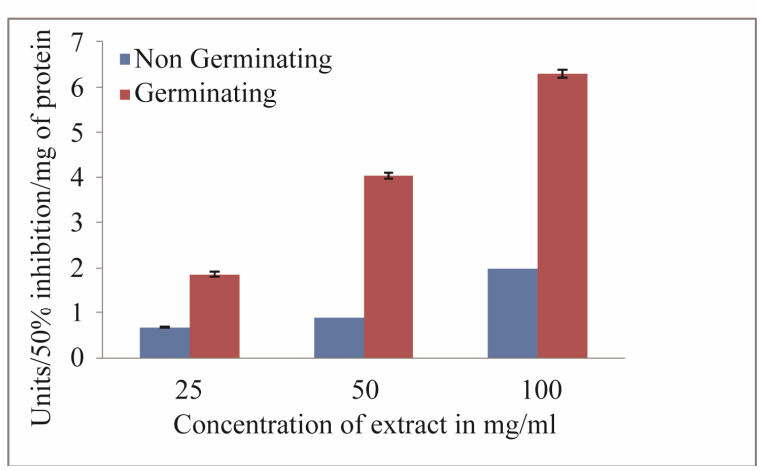

(b)

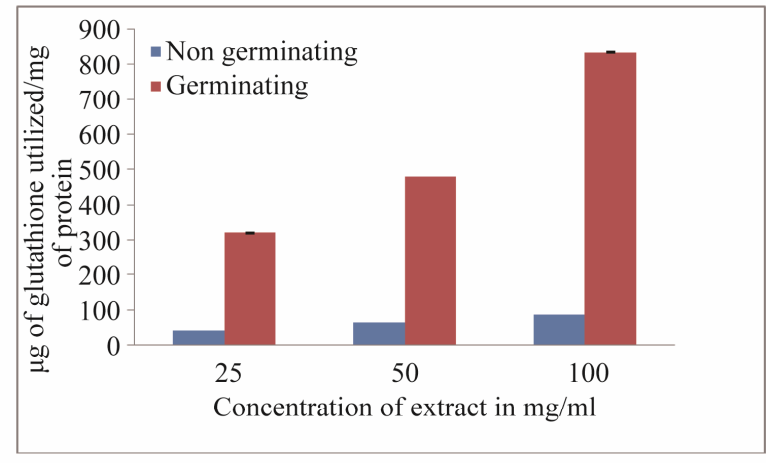

(d)

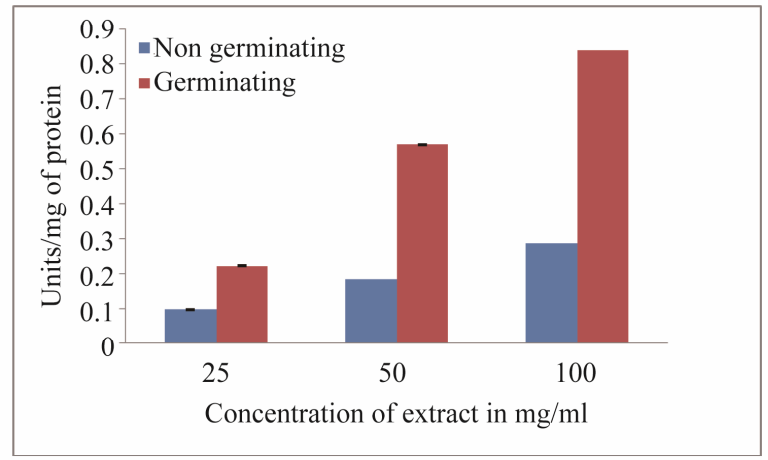

(f)

Figure 1. Levels of biochemical and antioxidant enzymes of Ceiba pentandra (kapok) seeds (a) Biochemical components; (b) SOD; (c) Catalase; (d) Glutathione peroxidase; (e) Peroxidase; (f) Ascorbate oxidase (values represent average of triplicates and expressed as mean $\pm \mathrm{SD})$.

as in the outer portions of the melon fruit mesocarp [37]. A similar expression pattern has also been found in noncucurbitaceous plants [38]. Thus AO-mediated oxidation of apoplastic L-AA appears to be closely linked to cell elongation processes. Our outcome was also in row with preceding reports and those were put on view in Figure 1(f).

\section{Conclusion}

The seeds of Ceiba pentandra were rich in proteins and carbohydrates, their levels decrease with the germination progress, indicating their key role in the growth of em- bryonic axis. Moreover, our findings strongly support the hypothesis that SOD, POD, CAT and AO activities are up-regulated as an antioxidant defense system against endogenous oxidant radicals generated during seed germination. The whole biological consequences of these alterations, in particular, low molecular mass antioxidants as well as altered antioxidant defense mechanisms during seed germination, are unclear and should be further investigated.

\section{Acknowledgements}

I Ch. Ravi Kiran, duly acknowledge the financial assis- 
tance from University Grants Commission, NON-SAP, New Delhi without which this project would never been materialized.

\section{REFERENCES}

[1] C. Bailly, "Active Oxygen Species and Antioxidants in Seed Biology," Seed Science Research, Vol. 14, No. 2, 2004, pp. 93-107. doi:10.1079/SSR2004159

[2] K. Apel and H. Hirt, "Reactive Oxygen Species: Metabolism, Oxidative Stress, and Signal Transduction," Annual Review of Plant Biology, Vol. 55, 2004, pp. 373-399. doi:10.1146/annurev.arplant.55.031903.141701

[3] C. Gapper and L. Dolan, "Control of Plant Development by Reactive Oxygen Species," Plant Physiology, Vol. 141, No. 2, 2006, pp. 341-345. doi:10.1104/pp.106.079079

[4] O. Blokhina, E. Virolainen and K. V. Fagerstedt, “Antioxidants, Oxidative Damage and Oxygen Deprivation Stress: A Review," Annals of Botany, Vol. 91, No. 2, 2003, pp. 179-194. doi:10.1093/aob/mcf118

[5] M. T. Le Paage-Degivry and G. Garello, "Embryo Dormancy in Taxus baccta: Influence of Culture Medium on Initiation of Germination," Plant Physiology, Vol. 29, 1973, pp. 204-207.

[6] J. A. Plummer and D. T. Bell, "The Effect of Temperature, Light and Gibberellic Acid $\left(\mathrm{GA}_{3}\right)$ on the Germination of Australian Everlasting Daisics (Asteraceae, Tribe Inulae)," Australian Journal of Botany, Vol. 43, No. 1, 1995, pp. 93-100. doi:10.1071/BT9950093

[7] N. Rajaram and K. Janardhanan, "Chemical Composition and Nutritional Evaluation of Certain Under-Exploited Vigna spp.," Food Sciences and Nutrition, Vol. 42, No. 4, 1990, pp. 213-221.

[8] O. H. Lowry, N. J. Rosebrough, A. L. Farr and R. J. Randall, "Protein Measurement with Folin Phenol Reagent," The Journal of Biological Chemistry, Vol. 193, No. 1, 1951, pp. 265-275.

[9] M. Dubois, K. A. Gilles, J. K. Hamilton, P. A. Rebers and F. Smith, "Colorimetric Method for Determination of Sugars and Related Substances," Analytical Chemistry, Vol. 28, No. 3, 1956, pp. 350-356. doi:10.1021/ac60111a017

[10] S. Moore and W. H. Stein, "A Modified Ninhydrin Reagent for the Photometric Determination of Amino Acids and Related Compounds," The Journal of Biological Chemistry, Vol. 211, 1954, pp. 907-913.

[11] Beuchamp and B. C. Fedovich, "Superoxide Dismutase assay and an Assay Applicable to Acrylamide Gel," Analytical Biochemistry, Vol. 10, 1976, pp. 276-287.

[12] C. Chance and Maehly, "Assay of Catalase and Peroxidase," Methods in Enzymology, Vol. 11, 1995, pp. 764775.

[13] C. P. Malik and M. B. Singh, "Plant Enzymology and Histoenzymology," Kalyani Publishers, New Delhi, 1980.

[14] J. T. Rotruck, A. L. Pope, H. E. Ganther, A. B. Swanson, D. G. Hafeman and W. G. Hoekstra, "Selenium: Biochemical Role as a Component of Glutathione Peroxi- dase," Science, Vol. 179, No. 4073, 1973, pp. 588-590. doi:10.1126/science.179.4073.588

[15] H. M. Vines and M. F. Oberbacher, "Response of Oxidation and Phosphorylation in Citrus Mitochondria to Arsenate," Nature, Vol. 206, No. 981, 1995, pp. 319-320. doi: $10.1038 / 206319 \mathrm{~b} 0$

[16] A. Ali Al-Heal, "Growth and Protein Content of Cassia senna L. Seedlings," Journal of the King Saud University -Science, Vol. 4, No. 1, 1992, pp. 5-13.

[17] M. Olczak, E. Niziol, W. Widlak and B. Morawiecka, "The Activity of Acid Phosphatase and the Level of Storage Proteins during the Early Stages of Germination of Lupinus luteus L. and Lupinus angustifolius L. Seeds," Acta Societatis Botanicorum Poloniae, Vol. 61, 1992, pp. 177-185.

[18] A. L. Tan-Wilson, X. W. Liu, R. Y. Chen, X. Q. Qi and K. A. Wilson, "An Acidic Amino Acid-Specific Protease from Germinating Soybeans," Phytochemistry, Vol. 42, No. 2, 1996, pp. 313-319. doi:10.1016/0031-9422(95)00896-9

[19] I. C. Obizaba and H. I. Egbuna, "Effect of Germination and Fermentation on the Nutritional Quality of Bambara Nut (Voandzeia subterranea L. Thouans) and Its Product (Milk)," Plant Foods for Human Nutrition, Vol. 42, No. 1, 1992, pp. 13-23. doi:10.1007/BF02196068

[20] S. Y. Giami, B. S. Chibor, K. E. Edebiri and S. C. Achinewhu, "Changes in Nitrogenous and Other Chemical Constituents, Protein Fractions and in Vitro Protein Digestibility of Germinating Fluted Pumpkin (Telfairia occidentalis Hook) Seed," Plant Foods for Human Nutrition, Vol. 53, No. 4, 1999, pp. 333-342. doi:10.1023/A:1008049712256

[21] R. Balasaraswathi and S. Sadasivam, "Changes in Oil, Sugar and Nitrogenous Components during Germination of Sunflower Seeds Helianthus annuus," Plant Foods for Human Nutrition, Vol. 51, No. 1, 1997, pp. 71-77. doi:10.1023/A:1007924026633

[22] T. V. Jaya and L. V. Venkataraman, "Changes in Carbohydrate Constituents of Chickpea and Greengram during Germination," Food Chemistry, Vol. 7, No. 2, 1981, pp. 95-104. doi:10.1016/0308-8146(81)90054-6

[23] S. Kon, A. C. Olson, D. P. Frederick, S. D. Eggling and J. R. Wagner, "Effect of Different Treatments on Phytate and Soluble Sugars in California Small White Beans (Phaseolus vulgaris)," Journal of Food Science, Vol. 38, No. 2, 1973, pp. 215-217. doi:10.1111/j.1365-2621.1973.tb01389.x

[24] R. Mittler, S. Vanderauwera, M. Gollery and F. Van Breusegem, "Reactive Oxygen Gene Network of Plants," Trends Plant Science, Vol. 9, No. 10, 2004, pp. 490-498. doi:10.1016/j.tplants.2004.08.009

[25] V. V. Rogozhin, V. V. Verkhoturov and T. T. Kurilyuk, "The Antioxidant System of Wheat Seeds during Germination," Biology Bulletin, Vol. 28, No. 2, 2001, pp. 126133. doi:10.1023/A:1009454713659

[26] T. Dučić, I. Lirić-rajlić, A. Mitrović and K. Radotić, “Activities of Antioxidant Systems during Germination of Chenopodium rubrum Seeds," Biologia Planttarum, Vol. 47, No. 4, 2003, pp. 527-533. 
[27] N. G. Lewis and E. Yamamoto, "Lignin: Occurrence, Biosynthesis and Biodegradation," Annual Review of Plant Physiology and Plant Molecular Biology, Vol. 41, 1990, pp. 455-496.

[28] F. Passardi, C. Cosio, C. Penel and C. Dunand, "Peroxidases Have More Functions than a Swiss Army Knife," Plant Cell Reports, Vol. 24, No. 5, 2005, pp. 255-265. doi:10.1007/s00299-005-0972-6

[29] H. Laloue, F. Weber-Lofti, A. Lucau-Danila and P. Guillemat, "Identification of Ascorbate and Guaiacol Peroxidase in Needle Chloroplasts of Spruce Trees," Plant Physiology and Biochemistry, Vol. 35, No. 5, 1997, pp. 341-346.

[30] T. Kawano, "Roles of the Reactive Oxygen SpeciesGenerating Peroxidase Reactions in Plant Defence and Growth Induction," Plant Cell Reports, Vol. 21, No. 9, 2003, pp. 829-837.

[31] O. Omidiji, J. Okpuzor and O. Otubu, "Peroxidase Activity of Germin Ating Sorghum bicolor Grains: Effect of Some Cations," Journal of the Science of Food and Agriculture, Vol. 82, No. 15, 2003, pp. 1881-1885. doi:10.1002/jsfa. 1144

[32] Ł. Wojtyla, M. Garnczarska, T. Zalewski, W. Bednarski, L. Ratajczak and S. A. Jurga, "Comparative Study of Water Distribution, Free Radical Production and Activation of Antioxidative Metabolism in Germinating Pea Seeds," Journal of Plant Physiology, Vol. 163, No. 12,
2006, pp. 1207-1220. doi:10.1016/j.jplph.2006.06.014

[33] F. A. Loewus, "L-Ascorbic Acid: Metabolism, Biosynthesis, Function," In: P. K. Stumpf and E. E. Conn, Eds., The Biochemistry of Plants: A Comprehensive Treatise, Academic Press, New York, 1980, pp. 77-101.

[34] O. Arrigoni, "Ascorbate System in Plant Development," Journal of Bioenergetics and Biomembranes, Vol. 26, No. 4, 1994, pp. 407-419.

[35] N. Kato and M. Esaka, "Changes in Ascorbate Oxidase Gene Expression and Ascorbate Levels in Cell Division and Cell Elongation in Tobacco Cells," Physiologia Plantarum, Vol. 105, No. 2, 1999, pp. 321-329. doi:10.1034/j.1399-3054.1999.105218.x

[36] L. S. Lin and J. E. Varner, "Expression of Ascorbic Acid Oxidase in Zucchini Squash (Curcubito pepo L.)," Plant Physiology, Vol. 96, No. 1, 1991, pp. 696-976. doi:10.1104/pp.96.1.159

[37] G. Diallinas, I. Pateraki, M. Sanmartin, A. Scossa, E. Stilanou, N. J. Panopoulos and A. K. Kanellis, "Melon Ascorbate Oxidase: Cloning of a Multigene Family, Induction during Fruit Development and Repression by Wounding," Plant Molecular Biology, Vol. 34, No. 5, 1997, pp. 759-770. doi:10.1023/A:1005851527227

[38] N. Kato and M. Esaka, "cDNA Cloning and Gene Expression of Ascorbate Oxidase in Tobacco," Plant Molecular Biology, Vol. 30, No. 4, 1996, pp. 833-837. doi:10.1007/BF00019015 